DIGITAL COMMONS
@ UNIVERSITY OF SOUTH FLORIDA

Volume 5

Issue 1 Volume 5.1 (Spring 2015)

\section{ABO: Interactive Journal for Women in the Arts, 1640-1830}

2015

\title{
Review of Amanda E. Herbert, Female Alliances: Gender, Identity, and Friendship in Early Modern Britain
}

Angela Rehbein

West Liberty University, angela.rehbein@westliberty.edu

Follow this and additional works at: https://digitalcommons.usf.edu/abo

Part of the Feminist, Gender, and Sexuality Studies Commons, and the Literature in English, British Isles Commons

\section{Recommended Citation}

Rehbein, Angela (2015) "Review of Amanda E. Herbert, Female Alliances: Gender, Identity, and Friendship in Early Modern Britain," ABO: Interactive Journal for Women in the Arts, 1640-1830: Vol.5: Iss.1, Article 5. http://dx.doi.org/10.5038/2157-7129.5.1.4

Available at: https://digitalcommons.usf.edu/abo/vol5/iss1/5

This Reviews is brought to you for free and open access by Digital Commons @ University of South Florida. It has been accepted for inclusion in ABO: Interactive Journal for Women in the Arts, 1640-1830 by an authorized administrator of Digital Commons @ University of South Florida. For more information, please contact digitalcommons@usf.edu. 
Review of Amanda E. Herbert, Female Alliances: Gender, Identity, and Friendship in Early Modern Britain

\author{
Abstract \\ Keywords \\ friendship, domesticity, alliance, women, gender \\ Creative Commons License \\ (c) $\odot \ominus$
}

Review of Amanda E. Herbert, Female Alliances: Gender, Identity, and Friendship in Early Modern Britain. New Haven: Yale UP, 2014. xi, 256 pages: illustrations; 24 cm. ISBN 978-0-300-17740-4.

This work is licensed under a Creative Commons Attribution-No Derivative Works 3.0 License. 
Amanda E. Herbert, Female Alliances: Gender, Identity, and Friendship in Early Modern Britain. New Haven: Yale UP, 2014. xi, 256 pages: illustrations; 24 cm. ISBN 978-0-300-177404.

Reviewed by Angela Rehbein

West Liberty University

Drawing upon an impressive range of archival materials, Amanda E. Herbert's Female Alliances argues that friendships between women offer vital information about the social construction of gender in the early modern period - in particular, that of what Herbert identifies as "elite women" (7) of the late seventeenth and early eighteenth centuries. Through instructive microhistories of women's gift production and exchange, their shared domestic labor, their socializing in public spas, and their missionary travels, among others, Herbert illuminates the many contexts in which early modern women formed and expressed bonds with one another. Often these bonds crossed boundaries between higher- and lower-status women, and Herbert cautions us not to assume animosity based on status alone. Defining "alliances" as "the wide variety of women's social activities and broadly positive interactions" (15), she contends that women of different ranks in society "not only inhabited many of the same spaces, but might also face real changes in their sources of income and employment over the course of their lifetimes" (8), making even more crucial their connections to one another.

Defining female alliances as "positive" interactions is crucial to Herbert's argument, as she asks us to rethink some common assumptions about gender and identity formation in the early modern period. She employs feminist theorist Sarah Lucia Hoagland's term "autokeonony," or the "self in community" (12), to argue that we should reconceive of the early modern female subject as the product of "relational acts of sociability" and "shared experiences of language, sympathetic emotion, and the physical body" (13), rather than as an autonomously-formed subject of isolation and self-regulation, a generally masculine (and generally negative, at least for women) conception of identity formation. Histories of prescriptive literature written for women, such as conduct manuals, have emphasized the restrictions such texts placed on women and the divisions that they created, as women monitored each other's adherence to patriarchal gender norms. Herbert, by contrast, while acknowledging that such norms did exist and were influential, nonetheless contends that "[t]he ability to relate to others, and especially to other women, was considered to be an essential component of this modern feminine identity" (13). Thus she highlights the spaces—domestic and foreign—in which such female alliances formed, and contends that they were frequently advantageous to the women who formed them.

Chapter one examines texts, mainly manuscript letters, written by women in order to uncover the "idioms and languages" that they used "to characterize their homosocial friendships" (23). Herbert shows that elite women often challenged or revised the contemporary philosophic, religious, medical, epistolary, and prescriptive discourses that placed them in subordinate positions. Early modern medical texts, for example, generally dismissed women as creatures of bodily passion, "lacking the dry, reasoned temperaments attributed to men" (32-33), while philosophic texts suggested that they were incapable of friendships based on perfect bonds between kindred souls (i.e. "masculine" friendships). In writing to their female friends and relatives, elite women adopted or rejected these claims: their "natural" emotional tendency, Herbert argues, is often construed positively within their letters and bolstered their passionate attachments to one another. Furthermore, discarding an exclusively masculine conception of true 
friendship, women "directly referenced the idea of shared souls when explaining their femalefemale alliances" (25). This chapter also highlights geographic challenges to female alliances, as women strove to maintain connections with friends in distant locations, such as colonial British America.

Chapters two, three, and four emphasize the material conditions of women's lives: the spaces in which they worked and socialized and the types of labor that they performed. Chapter two considers the practice of gift production and exchange, as Herbert unpacks the "specialized and gendered work" behind "a jar of marmalade, a bottle of perfume, a piece of embroidery, and a painted picture" (53). She argues that transforming commodities such as sugar and jewelry into marmalades and decorative art handwork, respectively, which were then given to female friends, allowed women to distance themselves from the morally-questionable circumstances in which such commodities were produced, such as the sugar plantation, and to bond with women who shared their "education, tastes, skills, and wealth" (77). Chapter three examines women's labor in gardens, kitchens, and bedchambers, which Herbert accesses via household inventories, prescriptive guidebooks, and "handwritten medical and culinary recipe books" (80). She contends that in these domestic spaces, women were expected to work collaboratively and cheerfully with one another, and that their marginalia in recipe books evinces their efforts to do so. In making this argument, Herbert performs deft close readings of frontispiece pictures and intext diagrams in prescriptive guidebooks such as R. Bradley's The Country Housewife and Lady's Director (1727) to show how visual and textual rhetoric worked together. Her skill in visual analysis is again displayed in chapter four, which fills a gap in our history of the public spa, generally considered a significant site in the Georgian period. Herbert uses Thomas Johnson's drawing “The King's and Queen's baths at Bath, looking West” (1675) to anchor her analysis and demonstrates that the spa was a space in which "women used their gendered experiences of child care, confectionary, handwork, and the provision of health care ... in order to enrich their female alliances" (141).

Herbert turns her attention to religious contexts in chapters five and six, examining the bonds formed between female Quaker missionaries (chapter five) and the experiences of a Nonconformist woman named Sarah Savage who struggled to perform the kinds of homosociability that were expected of her (chapter six). Herbert contends that Quaker women often sought the aid in their dangerous missionary travels from what they termed female "yokemates," or "devoted, long-term companions who shared an identity of religious purpose" (143). This chapter highlights the transoceanic nature of the British nation at this time, as Quaker women journeyed to British colonies in North America and the West Indies. Sarah Savage's diaries, which are the subject of chapter six, serve as a point of contrast in this study, as Savage had difficulty forming bonds with other women due to the divisions presented by her religious practices as a Nonconformist. That Savage struggled so mightily to connect with other women, Herbert argues, shows how salient female friendship was to an elite woman's identity at this time.

Herbert offers much rich textual evidence to support each of her claims, though I occasionally found myself desiring greater commentary on the status-crossing female alliances that she examines. For example, in chapter one, she considers letters written by Anne Cottrell Dormer to her sister Elizabeth Cottrell Trumbull, in which Dormer recounts tears shed by her female servant, called Frances or "Frank," upon her leaving to work in a different household. Dormer writes that Frank "wept extreamly to leave me"; Frank's replacement, Doll, "has shewed much 
love and concern for me of late and weeps when her Mr. is cross" (qtd. on 36). Herbert uses this evidence to show that "[a]cts of passionate weeping were also called on by lower-status women to express loyalty to their elite employers": she claims that "Doll's and Frank's performative tears were signs that the women were 'honest' and 'very faithfull,", and that "Dormer's relationships with her female servants were meaningful to her and made more emotionally rich to Dormer by the performance of mourning and tears" (36, my emphasis). As Herbert openly acknowledges in her introduction, it is the literate woman's experience that is most accessible to us, and "these elite women certainly lived far better than a majority of seventeenth- and eighteenth-century Britons, female or male" (7). As such, I find myself somewhat skeptical of the idea that such an exchange is an example of a "broadly positive interaction," as Herbert defines female alliances. Such claims might not give us the full picture of the social hierarchy at work - or, at least, Herbert might more fully explicate the ways that this was a positive alliance for Frank and Doll, especially as their own accounts do not seem to survive.

All told, I learned much by reading this wide-ranging and lucid book, and it makes a significant contribution to our histories of women's lives and labors and the role that they played in the formation of the British nation. 